\title{
Alfons Maria Jakob (1884-1931), Neuropathologist par Excellence
}

\section{Scientific Endeavors in Europe and the Americas}

\author{
Lazaros C. Triarhou \\ Economo-Koskinas Wing for Integrative and Evolutionary Neuroscience, Department of Educational and \\ Social Policy, University of Macedonia, Thessaloniki, Greece
}

\section{Key Words}

Alfons Maria Jakob $\cdot$ Alpers disease $\cdot$ Creutzfeldt-Jakob disease $\cdot$ History of neuroscience $\cdot$ History of neuropathology

\begin{abstract}
The study briefly reviews the life and work of Alfons Maria Jakob (1884-1931), a notable representative of pre-war German neuropathology. Today Jakob is mainly remembered by neurologists for the spongiform encephalopathy with progressive dementia and spasticity that he, and Kiel neuropathologist Hans Gerhard Creutzfeldt (1885-1964), described independently. However, Jakob has left additional contributions to neuroanatomy, neuropathology and neuropsychiatry in the form of original articles and valuable monographs.

Copyright $\odot 2008$ S. Karger AG, Base
\end{abstract}

A notable representative of German neuropathology [1-3], Bavarian neurologist Alfons Maria Jakob (fig. 1), was born on July 2, 1884 in Aschaffenburg am Main to a family of retailers. He studied medicine at the Universities of München, Berlin and Strassburg.

\section{KARGER}

Fax +41 613061234 E-Mail karger@karger.ch www.karger.com
(C) 2008 S. Karger AG, Base

0014-3022/09/0611-0052\$26.00/0

Accessible online at:

www.karger.com/ene

\section{First Publications and Academic Career}

The first scientific publication of Alfons Jakob dealt with the symptomatology, pathogenesis and pathological anatomy of the 'circular psychoses' [4]. Jakob completed his doctoral thesis on July 13, 1909 under the supervision of Robert Wollenberg (1862-1942), professor of psychiatry at Kaiser-Wilhelms-Universität Strassburg, on 'the pathogenesis of pseudobulbar palsy' [5] - a lower cranial nerve palsy resulting from supranuclear lesions, so named in 1877 by Lyon physiologist and Charcot student JacquesRaphaël Lépine (1840-1919). Jakob reviewed 115 literature cases and clinicopathologically studied a 55-year-old male with cerebral atrophy, encephalomalacia multiplex, and circumscribed cerebellar hemorrhage.

On December 1, 1909 Jakob became an assistant physician at the psychiatric clinic directed by Emil Kraepelin (1856-1926) in München, where he trained in neuroanatomy with Alois Alzheimer (1864-1915) through May 1, 1911 [1].

Solicited by professor Wilhelm Weygandt (18701939), he moved in November 1911 to the psychiatric clinic of the Friedrichsberg State Hospital in Hamburg, where he eventually succeeded Theodor Kaes (18521913) as director (Prosektor) of the neuroanatomical lab-

Lazaros C. Triarhou, $\mathrm{MD}, \mathrm{PhD}$

University of Macedonia

Egnatia 156, Bldg. Z-312

GR-54006 Thessaloniki (Greece)

Tel. +30 2310891 387, Fax +30 2310891 388, E-Mail triarhou@uom.gr 
oratory. From the summer of 1915 until the end of World War I, Jakob served as a medical officer at the Belgian front. He was habilitated in neurology and psychiatry at Hamburg University in 1919 and became professor in 1924. He expanded the laboratory with serology, genetics, and experimental psychology sectors, and trained dozens of students from the United States, Russia, Japan, Turkey, Italy, Switzerland, Spain, Portugal and Uruguay [1]. He also kept a reputable medical practice. His brother Franz, also a physician, practiced in Nürnberg [6].

\section{Creutzfeldt-Jakob Disease}

At the 10th annual meeting of the Society of German Neurologists, held in Leipzig on September 18, 1920, O.B. Meyer presiding, von Weizsäcker read Jakob's report describing a clinicopathological syndrome in 3 patients $(2$ female, 51 and 34 years old, and 1 male, 43 years old) with spasticity and progressive dementia associated with cortical, striatal and spinal degeneration [7]. Jakob [8] expanded on those 3 cases in an additional paper. In 1920, Kiel neuropathologist Hans Gerhard Creutzfeldt (18851964) had independently published a similar case of a 22 year-old woman [9]. The text that follows gives an overview of what Jakob and additionally Creutzfeldt really described, compared to our current knowledge on spongiform encephalopathies. In-depth accounts have been given by Duckett and Stern [10], Poser and Bruyn [11], and Wolf and Foley [12].

'Creutzfeldt-Jakob disease' (CJD) was so named by Spielmeyer [13] and subsequently included amongst the organic psychoses in Bumke's 1928 Handbook of Mental Diseases [12]. The CJD concept is closer to a neuropathological syndrome rather than a single etiologic-nosological entity $[10,14]$. Some 84 forms, 'types' or variants of CJD have been recorded on the basis of clinical and neuropathological criteria [15].

Today, CJD is classified as a prion disease ('prionosos') or transmissible spongiform encephalopathy (TSE), characterized by dementia, pyramidal, and extrapyramidal signs clinically, and by neuronal loss, spongiform changes, and astroglial reaction histologically $[11,12]$.

Scientific interest in CJD became renewed in 1957 with the description of kuru, a contagious disorder in natives of New Guinea [16] and its similarities to scrapie, a transmissible infectious disease in sheep $[17,18]$; the concept of prion diseases was formulated 25 years later [19]. Animal forms of TSE, besides scrapie, include bovine

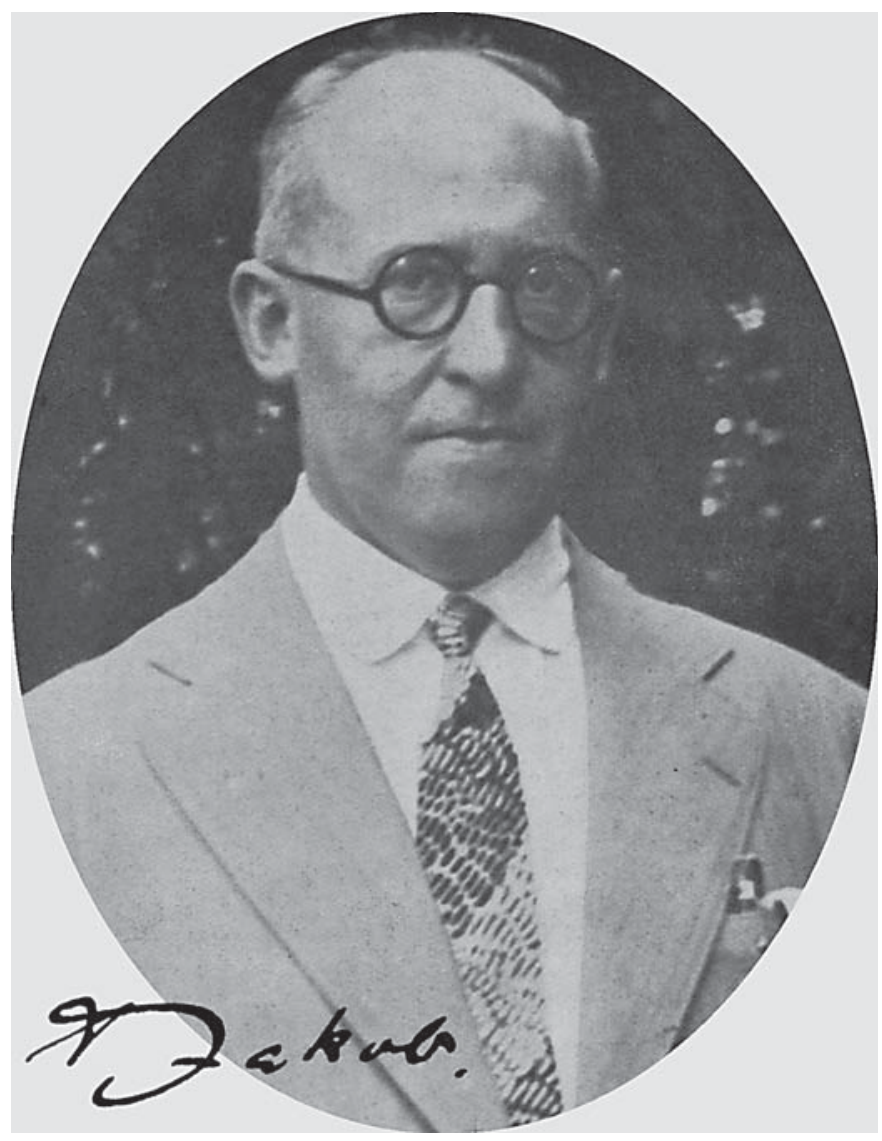

Fig. 1. Professor Alfons Maria Jakob (1884-1931). Photo from Brazilian textbook [36]; signature from an original offprint of his first article [4], hand-inscribed to Viennese neuropsychiatrist Erwin Stransky (1878-1962).

spongiform encephalopathy ('mad cow disease') and mink encephalopathy [11].

In all, Creutzfeldt studied 1 case $[9,20]$, and Jakob 7 cases, including the initial 3 cases [7, 8], case 4 [21], and case 5 described in his book on extrapyramidal disorders [22]. The brains of Jakob's patients 6 and 7 were further studied and published posthumously by his pupil Kirschbaum [23], who in his monograph reviewed 150 cases of CJD gathered over a 50-year period, including Creutzfeldt's and Jakob's original cases. English translations of Creutzfeldt's first paper [9] and of Jakob's report on case 4 [21] may be found in Rottenberg and Hochberg [24].

Creutzfeldt's case concerned a patient seen in 1913 at Alzheimer's clinic in Breslau. Because of World War I and Alzheimer's death, Creutzfeldt finalized his manuscript [9] after his 1919 move to Spielmeyer's department in Munich. Creutzfeldt published a sequel paper on the case [20]. 
Both articles were entitled 'On a particular focal illness of the central nervous system', conveying the possibility of having identified a new entity of unknown etiology [10].

The patient first presented with gait ataxia and developmental behavioral abnormalities when she was 16 [12]. The disease progressed irregularly, with remissions. The later clinical picture included pyramidal signs (paresis, spasticity and bilateral Babinski), hyperalgesia, intention tremor, facial hyperkinesia, nystagmus, myoclonus, dementia, mood changes and mutism [11]. Erythema multiforme bullosum, appearing as herpetiform small vesicles, made its appearance in the vicinity of the third ramus of the left trigeminal nerve. Stupor deepened, swallowing became impaired, and death ensued in status epilepticus $[9,10]$. Two of the patient's five siblings had mental deficits and her mother had died of an unknown cause at the age of 56 .

The neuropathological finds were focal neuron loss and neuronophagia in the postcentral and precentral gyri (particularly affecting the pyramidal cells of the third and deeper layers), bilateral degeneration of the corticospinal tracts, vascular reaction and astroglial hypertrophy also present in the basal ganglia, thalamus, cerebellum, brainstem and spinal cord [10]. Status spongiosus was not reported [11]. The diagnosis was an acquired polioencephalopathy. Creutzfeldt's case may actually be the first report of herpes zoster encephalopathy [10].

Jakob's first 5 cases $[7,8,21,22]$ and Creutzfeldt's case $[9,20]$ shared, in Jakob's opinion, a common neuropathological picture, a polioencephalopathy with lesions in the frontal lobe (deep cortical layers in particular) and changes in the rest of the cortex, striatum, thalamus (medioventral and lateral nuclei), substantia nigra, pontine tegmentum, cerebellum, brainstem and spinal cord. Jakob did not regard his first 4 cases as a homogenous group [10] and thought that the bulk of the pathological changes fell on the extrapyramidal system [25]. Diagnosis in cases 1 and 2 was syphilis, in case 3 malaria, and in case 4 chronic alcoholism $[7,8,21]$. In all likelihood, the diagnosis of CJD was correct in Jakob's case 3, the patient with progressive dementia, leg weakness and pain, ataxia, vertigo and diplopia $[7,8]$, and in case 5 [22], with diffuse vacuolation of the neuropil throughout cerebral cortical areas and the cerebellar molecular layer, typically seen in TSEs [11]. It is also interesting to note that the sister and maternal grandmother, along with 8 of her siblings, of Jakob's patient 6 , a 44-year-old male, had died of an undeciphered nervous disorder; the brains of patient 6 , his sister, and two of his children contained spongiform changes [11].
Jakob gave the disorder a neuropathological rather than a clinical name, 'spastic pseudosclerosis encephalopathy with disseminated foci of degeneration' [10]. He designated his subgroup of pseudosclerosis 'spastic', owing to the marked corticospinal degeneration $[11,12,26]$. Having access to Creutzfeldt's slides and the galleys of Creutzfeldt's chapter [20], Jakob considered Creutzfeldt's case as another example of spastic pseudosclerosis. However, Creutzfeldt objected to the term 'spastic pseudosclerosis' [11], preferring instead the general description 'progressive focal and diffuse degeneration of the gray matter' [10] and provisionally leaving the disorder without a specific clinical name [12].

The term 'pseudosclerosis' had been introduced in 1883 by the Berlin neuropsychiatrist Carl Westphal (1833-1890) [27] to describe what would later be identified as a juvenile form (Westphal variant) of Huntington chorea [28]. The eponym Westphal-Strümpell pseudosclerosis was also adopted in the German literature, based on additional cases reported by the Erlangen internist Adolf von Strümpell (1853-1925) in children [29].

A 'singular' case of pseudosclerosis with tonic rigidity and high-grade dementia, but without Babinski sign, sensory disturbances or thalamic lesions [30], marked histopathologically by interstitial hepatitis, gliosis in the striatum and globus pallidus, substantia innominata and cerebellar molecular layer, was reported by Economo and Schilder [31] in a 55-year-old man, before Creutzfeldt's first study [9] in the same journal. Although at some point considered to bear similarities with the classical descriptions of CJD [32], that case was probably Wilson disease [33]. Economo and Schilder [31] had inferred that their case affected the extrapyramidal system, with a distant relationship to paralysis agitans and olivopontocerebellar atrophy. Jakob [7] did observe interesting similarities between his first 3 cases and that of Economo and Schilder [31], but pinpointed that the latter was accompanied by liver damage, and thus found an agreement of his cases in all the substantial points only with the case of Creutzfeldt [9].

The question has been raised whether the disease that Creutzfeldt and Jakob independently described is the same, and the validity of Creutzfeldt's case report [9] as an instance of 'classical' CJD has been disputed [11, 12] on grounds of the patient's young age, the developmental symptoms, and the absence of extrapyramidal signs. Kirschbaum [23] and Katscher [34] favor 'Jakob-Creutzfeldt disease' (or 'Jakob's syndrome' [23]) over CJD, crediting Jakob as the major contributor to CJD, and a majority of authors currently consider Jakob's cases as the first 
true descriptions of CJD [10]. Proof that Jakob's later patients were true cases of CJD came with the identification of a PRNP gene mutation [35].

Thus, one may conceivably discern a connection between Jakob's 'syndrome' and the seeds for the eventual bestowal of two of the Swedish Academy's summa cum laude Prizes in Physiology or Medicine: to D. Carleton Gajdusek (and Baruch S. Blumberg) in 1976 'for their discoveries concerning new mechanisms for the origin and dissemination of infectious diseases', and to Stanley B. Prusiner in 1997 'for his discovery of prions, a new biological principle of infection'.

\section{Travels to the Americas}

On 27 March 1924, Jakob embarked on the maiden voyage of the Hamburg-American ocean liner Deutschland from Southampton, arriving in New York on April 6 [6]. He guest lectured at several institutions, including Columbia University [14].

Four years later, he journeyed to Latin America. In May through July 1928, he gave a 20-lecture course in Rio de Janeiro on nervous and mental pathology (fig. 2), with a theoretical and a practical part, using 4,000 microscopic preparations and transparencies [36]. He then travelled to São Paulo and Campinas, Brazil; Buenos Aires, where he met with physiologist Bernardo Alberto Houssay (1887-1971) and visited the neuroanatomical institute of his fellow countryman, Bavarian neuropathologist Christfried Jakob (1866-1956) [37, 38]; over the imposing Cordillera to Santiago de Chile and Valparaiso; and back, over the Andes, to Montevideo, Uruguay. Jakob gave a presentation of his South American impressions to the Hamburg Medical Association on December 11, 1928 [39].

\section{Authored Works}

Jakob published 80 articles on diverse topics [1-3], including cerebellar tumors (1910), trauma and secondary fiber degeneration (1912), cerebellar ataxia [40], multiple sclerosis (1913), epilepsy (1914), diffuse infiltrating encephalomyelitis (1914), spinal cord concussion (1919), endarteriitis syphilitica (1920), paralysis and tabes (1922), megalencephaly (1925), miliary gummata [41], and yellow fever [42], the latter co-authored with Amadeu Fialho and Eudoro Libanio Villela and presented at the 19th annual meeting of the Society of German Neurologists on

\section{Curso de Anatomia Pathologica}

DO

Systema Nervoso

PELO

Prof. AIfons JAKOB

(DA UXIVERSIDADE DE HAMBURGO)

(Conferencias realisadas de Maio a Julho de

1928 no Rio de Janeiro)

PREFACIO DO PROFESSOR A. AUSTREGESILO

COMMISSTOO ORGHNISHDORT

Ulysses Vianna-Presidente

Arthur Moses - Secretario

Waldemar de Almeida - Thesoureiro

2.: Ediçåo revista e augmentada

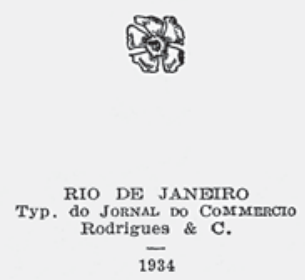

Fig. 2. Frontispiece of the second edition of Jakob's book containing his Brazilian lectures, published posthumously [36].

20 September 1929 in Würzburg, chaired by Otfrid Foerster (1873-1941). He published a review in Spanish on anatomo-psychiatric correlations [43] and one in Portuguese on multiple sclerosis [44]. Jakob was one of the proponents of the value of histopathology for elucidating the research problems of psychiatric diseases $[25,45]$.

Jakob wrote the cerebellar chapter for Möllendorff's 1928 Handbook of Microscopic Anatomy, and the neurosyphilis chapter for Bumke's 1930 Handbook of Mental Diseases [2,3]. He authored a monograph on extrapyramidal disorders [22], and contributed two scholarly volumes to Aschaffenburg's Handbook of Psychiatry, on normal and pathological neuroanatomy and neurohistology [46] and on special cerebral histopathology [47].

Jakob reviewed the Cytoarchitectonics of the Adult Human Cerebral Cortex of Economo and Koskinas [48] and the Icones Neurologicae of Strümpell and C. Jakob [49]. Strümpell and C. Jakob had produced the original epitome of Icones Neurologicae in 1897 [50]; the plates were 
re-edited by Müller and Spatz in 1926 with 13 folded plates, 11 of them $106 \times 140 \mathrm{~cm}$ in size and two $140 \times$ $212 \mathrm{~cm}$ [51].

Jakob called the Economo and Koskinas Cytoarchitectonics 'a masterpiece unique in the international medical literature', its 112 plates 'brilliant achievements in scientific microphotography', and its text a 'joy to the reader' [48]. Jakob found the nomenclature of Economo and Koskinas 'fully meaningful' in its departure from the methods of Vogt and Brodmann. In his own textbook on Cerebral Anatomy and Histology, Jakob [46] devoted twothirds of the chapter on the architectonic organization of cortical fields to the findings of Economo and Koskinas and reproduced 23 of their original figures, arguing that 'at last we have acquired a perfect and complete map of the cerebral cortex by areas' [48].

Jakob is described as a 'private and disciplined individual, excellent and knowledgeable teacher and charismatic leader' [10]. Besides his own publications, Jakob conceived, and in part dictated, an estimated further 80 works by his students, in which he does not appear as a co-author [1].

\section{Alpers Disease}

At the third session of the 20th annual meeting of the Society of German Neurologists in Dresden on 20 September 1930, H. Curschmann presiding, Jakob presented a yet another new entity [52], studied in conjunction with his pupils Somoza, Freedom [53] and Alpers [54]. 'Alpers disease' or progressive infantile poliodystrophy (also called spongy glio-neuronal dystrophy [55]) is a mitochondrial disorder with autosomal recessive inheritance appearing in early infancy [56-58], leading to marked de- mentia, prominent seizures, spasticity and opisthotonus, and accompanied by liver failure $[59,60]$. The histological hallmarks include almost total neuronal loss in the cortical gray matter with spongy changes and astrogliosis, and the molecular genetic defect is associated with mutations in the polymerase- $\gamma(P O L G)$ gene of the mitochondrial DNA (mtDNA) [61-63].

\section{Postscript}

Jakob gave his 'swan-song' presentation, on the nosology and localization of torsion dystonia with cinematographic and anatomical demonstrations, at the First International Neurological Congress in Berne [64], during the clinical-pathogenetic section of the afternoon of 3 September 1931, chaired by Gheorghe Marinescu (18631938).

Shortly after the Berne Congress, neurology lost two of its protagonists: Alfons Jakob on October 17, 1931 in Hamburg, at the age of 47, after an operation to contain complications of streptococcal osteomyelitis, from which he had been suffering for 7 years; and, within 4 days, Constantin von Economo in Vienna, at the age of 55. Three years later to the day, on October 17, 1934, the neuroscience world would lose yet another of its greatest, the venerated Santiago Ramón y Cajal.

\section{Acknowledgements}

The author gratefully acknowledges the courtesy of the Öffentliche Bibliothek der Universität Basel, Switzerland, for bibliographic assistance, and the Research Committee of the University of Macedonia, Greece, for subsidizing in part the publication costs.

\section{References}

1 Weygandt W: Zum Andenken an Professor Jakob. Dtsch Z Nervenheilk 1931;123:I-IV.

2 Lüthy F: Alfons Jakob. Schweizer Arch Neurol Psychiatr 1932;29:189-191.

3 Hassin GB: Alfons Maria Jakob (1884-1931); in Haymaker W (ed): The Founders of Neurology. Springfield, Thomas, 1953, pp 184186.

4 Jakob A: Zur Symptomatologie, Pathogenese und pathologischen Anatomie der 'Kreislaufspsychosen'. J Psychol Neurol (Leipz) 1909;14:209-248, 1909;15:99-132.
5 Jakob A: Die Pathogenese der Pseudobulbärparalyse. Arch Psychiatr Nervenkrankh 1909;45:1097-1228.

6 Ancestry.com: New York Passenger Lists, 1820-1957. Provo, The Generations Network, Inc., 2006.

7 Jakob A: Über eigenartige Erkrankungen des Zentralnervensystems mit bemerkenswertem anatomischem Befunde (Spastische Pseudosklerose-Encephalomyelopathie mit disseminierten Degenerationsherden). Dtsch Z Nervenheilk 1921;70:132-146.
-8 Jakob A: Über eigenartige Erkrankungen des Zentralnervensystems mit bemerkenswertem anatomischem Befunde (Spastische Pseudosklerose-Encephalomyelopathie mit disseminierten Degenerationsherden). Z Gesamte Neurol Psychiatr 1921;64:147-228.

$\checkmark$ Creutzfeldt HG: Über eine eigenartige herdförmige Erkrankung des Zentralnervensystems. Z Gesamte Neurol Psychiatr 1920;57: $1-18$.

10 Duckett S, Stern J: Origins of the Creutzfeldt and Jakob concept. J Hist Neurosci 1999;8: 21-34. 
11 Poser CM, Bruyn GW: Creutzfeldt-Jakob disease; in Koehler PJ, Bruyn GW, Pearce JMS (eds): Neurological Eponyms. New York, Oxford University Press, 2000, pp 283290

12 Wolf JH, Foley P: Hans Gerhard Creutzfeldt (1885-1964): a life in neuropathology. J Neural Transm 2005;112:I-XCVII.

$\checkmark 13$ Spielmeyer W: Die histopathologische Forschung in der Psychiatrie. Klin Wochenschr 1922;1:1817-1819.

14 Jakob A: The anatomy, clinical syndromes and physiology of the extrapyramidal system. Arch Neurol Psychiatry 1925;13:596620 .

15 Masters CL: Creutzfeldt-Jakob disease: its origins. Alzheimer Dis Assoc Disord 1989;3: 46-51.

16 Gajdusek DC, Zigas V: Degenerative disease of the central nervous system in New Guinea; the endemic occurrence of kuru in the native population. N Engl J Med 1957;257:974978.

17 Hadlow WJ: Scrapie and kuru. Lancet 1959; 274:289-290.

18 Klatzo I, Gajdusek DC, Zigas V: Pathology of kuru. Lab Invest 1959;8:799-847.

19 Prusiner SB: Novel proteinaceous infectious particles cause scrapie. Science 1982;216: 136-144.

20 Creutzfeldt HG: Über eine eigenartige herdförmige Erkrankung des Zentralnervensystems; in Nissl F, Alzheimer A (eds): Histologische und histopathologische Arbeiten über die Grosshirnrinde. Jena, Gustav Fischer, 1921, pp 1-48.

21 Jakob A: Über eine der multiplen Sklerose klinisch nahestehende Erkrankung des Zentralnervensystems (spastische Pseudosklerose) mit bemerkenswertem anatomischem Befunde. Mitteilung eines vierten Falles. Med Klin 1921;17:372-376.

22 Jakob A: Die extrapyramidalen Erkrankungen mit besonderer Berücksichtigung der pathologischen Anatomie und Histologie und der Pathophysiologie der Bewegungsstörungen. Berlin, Julius Springer, 1923.

23 Kirschbaum WR: Jakob-Creutzfeldt disease (Spastic Pseudosclerosis, A. Jakob; Heidenhain Syndrome; Subacute Spongiform Encephalopathy). New York, American Elsevier, 1968.

24 Rottenberg DA, Hochberg FH: Neurological Classics in Modern Translation. New York, Hafner, 1977.

-25 Jakob A: Die Histopathologie im Dienste der psychiatrischen Krankheitsforschung. Arch Psychiatr Nervenkrankh 1927;81:68-98.

26 Jakob A: Über drei eigenartige Krankheitsfälle des mittleren Alters mit bemerkenswertem, gleichartigem anatomischem Befunde und ihre klinischen und anatomischen Beziehungen zur spastischen Pseudosklerose und zu metencephalitischen Prozessen. Dtsch Z Nervenheilk 1924;81:192-204.
27 Westphal C: Ueber eine dem Bilde der cerebrospinalen grauen Degeneration ähnliche Erkrankung des centralen Nervensystems ohne anatomischen Befund, nebst einigen Bemerkungen über paradoxe Contraction. Arch Psychiatr Nervenkrankh 1883;14:87134, 767-769.

28 Holdorff B: Pioneers in Neurology: Carl Westphal (1833-1890). J Neurol 2005;252: 1288-1289.

-29 von Strümpell A: Ueber die Westphal'sche Pseudosklerose und über diffuse Hirnsklerose, insbesondere bei Kindern. Dtsch Z Nervenheilk 1898;12:115-149.

-30 Jacob H, Pyrkosch W, Strube H: Die erbliche Form der Creutzfeldt-Jakobschen Krankheit (Familie Backer). Arch Psychiatr Z Neurol 1950;184:653-674.

31 Economo C, Schilder P: Eine der Pseudosklerose nahestehende Erkrankung im Praesenium. Z Gesamte Neurol Psychiatr 1920; 55:1-26.

32 Liberski PP, Budka H: An overview of neuropathology of the slow unconventional virus infections; in Liberski PP (ed): Light and Electron Microscopic Neuropathology of Slow Virus Disorders. Boca Raton, CRC Press, 1993, pp 111-149.

33 Ransmayr G: Constantin von Economo's contribution to the understanding of movement disorders. Mov Disord 2007;22:469475 .

34 Katscher F: It's Jakob's disease, not Creutzfeldt's. Nature 1998;393:11.

35 Brown P, Cervenáková L, Boellaard JW, Stavrou D, Goldfarb LG, Gajdusek DC: Identification of a PRNP gene mutation in Jakob's original Creutzfeldt-Jakob disease family. Lancet 1994;344:130-131.

36 Jakob A: Curso de anatomia pathologica do systema nervoso, $2^{\mathrm{a}}$ edição revista e augmentada. Rio de Janeiro, Rodrigues \& Companhia, 1934.

37 Triarhou LC, del Cerro M: Semicentennial tribute to the ingenious neurobiologist Christfried Jakob (1866-1956). 1. Works from Germany and the first Argentina period, 1891-1913. Eur Neurol 2006;56:176188.

38 Triarhou LC, del Cerro M: Semicentennial tribute to the ingenious neurobiologist Christfried Jakob (1866-1956). 2. Publications from the second Argentina period, 1913-1949. Eur Neurol 2006;56:189-198.

39 Jakob A: Reisebrief aus Südamerika. Dtsch Med Wochenschr 1929;55:281-282, 320-321, 365-368.

40 Jakob A: Zur Klinik und pathologischen Anatomie des chronischen Alkoholismus zugleich ein Beitrag zu die Erkrankungen des Kleinhirns. Z Gesamte Neurol Psychiatr 1912;13:132-152.

41 Jakob A: Über den Befund von miliaren Gummen bei der Paralyse. Z Gesamte Neurol Psychiatr 1926;102:313-319.
42 Jakob A, Fialho A, Villela EL: Über die Veränderungen im Zentralnervensystem bei Gelbfieber. Dtsch Z Nervenheilk 1929;111: 111-116.

43 Jakob A: Investigaciones de anatomía cerebral y neuro-psiquiatría clínica. Rev Méd Germano-Ibero-Amer 1928;1:159-169.

44 Jakob A: Concepcão actual da esclerose multipla. Brasil Med 1931;45:1101-1103.

45 Jakob A: Die Bedeutung der Histopathologie des Zentralnervensystems für die Erforschung der Geisteskrankheiten. Münch Med Wochenschr 1920;67:875-878.

46 Jakob A: Normale und pathologische Anatomie und Histologie des Grosshirns (mit besonderer Berücksichtigung der Histopathologie der Psychosen und extrapyramidalen Erkrankungen), erster Band: Normale Anatomie und Histologie und allgemeine Histopathologie des Grosshirns. Leipzig/Wien, Franz Deuticke, 1927.

47 Jakob A: Spezielle Histopathologie des Grosshirns, erster Teil. Leipzig/Wien, Franz Deuticke, 1929.

48 Jakob A: Referatenteil, Nerven- und Geisteskrankheiten: Die Cytoarchitektonik der Hirnrinde des erwachsenen Menschen. Von C. Freiherrn von Economo und G. N. Koskinas. Klin Wochenschr (Berl) 1926;5:37-38.

49 Jakob A: Bücherbesprechungen. Strümpell und Jakob, Icones neurologicae. Dtsch Z Nervenheilk 1927;98:154-157.

50 Strümpell A, Jakob C: Neurologische Wandtafeln zum Gebrauche beim klinischen, anatomischen und physiologischen Unterricht. München, Lehmann, 1897.

51 Strümpell A, Jakob C: Icones Neurologicae. Bilder zur makroskopischen Anatomie des Gehirns und zum Bahnenverlauf (Erläuterungen zur 2. Auflage von F. Müller und H. Spatz). München, Lehmann, 1926.

52 Jakob A: Über eigenartige frühinfantil einsetzende Erkrankungen des Großhirns mit besonderer Bevorzugung der grauen Sub$\operatorname{stanz}$ (Grosshirnrinde, Striatum, Pallidum und Thalamus). Dtsch Z Nervenheilk 1930; 116:240-253.

53 Freedom L: Über einen eigenartigen Krankheitsfall des jugendlichen Alters unter dem Symptomenbilde einer Littleschen Starre mit Athetose und Idiotie. Dtsch Z Nervenheilk 1927;96:295-298.

54 Alpers BJ: Diffuse progressive degeneration of the gray matter of the cerebrum. Arch Neurol Psychiatry 1931;25:469-505.

55 Jellinger K, Seitelberger F: Spongy glio-neuronal dystrophy in infancy and childhood. Acta Neuropathol 1970;16:125-140.

56 Sandbank U, Lerman P: Progressive cerebral poliodystrophy - Alpers' disease: disorganized giant neuronal mitochondria on electron microscopy. J Neurol Neurosurg Psychiatry 1972;35:749-755.

57 Prick MJJ: Progressive Poliodystrophy: Association with Disturbances in Pyruvate Metabolism. Wijcken (Holland), Drukkerij Dukenburch, 1983. 
-58 Egger J, Pincott JR, Wilson J, Erdohazi M: Cortical subacute necrotizing encephalomyelopathy: a study of two patients with mitochondrial dysfunction. Neuropediatrics 1984;15:150-158.

59 Aicardi J: Diseases of the Nervous System in Childhood. London, MacKeith Press, 1992, pp 527-529.

60 Neville BGR, Collins JE, Surtees RAH: Paediatric neurology; in Walton J (ed): Brain's Diseases of the Nervous System, ed 10. Oxford, Oxford University Press, 1993, pp 453477.
61 Nguyen KV, Østergaard E, Ravn SH, Balslev T, Danielsen ER, Vardag A, McKiernan PJ, Gray G, Naviaux RK: POLG mutations in Alpers syndrome. Neurology 2005;65:14931495.

62 Ferrari G, Lamantea E, Donati A, Filosto M, Briem E, Carrara F, Parini R, Simonati A, Santer R, Zeviani M: Infantile hepatocerebral syndromes associated with mutations in the mitochondrial DNA polymerase- $\gamma \mathrm{A}$. Brain 2005; 128:723-731.
63 Davidzon G, Mancuso M, Ferraris S, Quinzii C, Hirano M, Peters HL, Kirby D, Thorburn DR, DiMauro S: POLG mutations and Alpers syndrome. Ann Neurol 2005;57:921-923.

64 Jakob A: Zur Frage der nosologischen und lokalisatorischen Auffassung der torsiondystonischen Krankheitserscheinungen; in Brouwer B, Sachs B, Riley HA, Dubois C, Fischer RF von, Schnyder P (eds): Comptes Rendus du ler Congrès Neurologique International. Berne, Stämpfli, 1932, pp 255256. 